\title{
25
}

\section{Holding individuals to account beyond the state? Rights, regulation and the resort to international criminal responsibility}

\section{Michelle Burgis-Kasthala}

\section{Introduction: Understanding international criminal law as governance}

International law as a discipline and practice comprises a number of overlapping and sometimes conflicting regimes for the regulation of relations between states as well as, increasingly, various relations within and across states (Koskenniemi 2007). This chapter considers the rise of international criminal law (ICL) as a particular technique of governance that both builds on other international legal regimes and marks a departure in its practices and effects. ICL is concerned with holding individuals criminally responsible for various crimes that have become internationalised including the well-known singular crimes of piracy, slavery, genocide and apartheid as well as a whole range of offences under the broad headings of war crimes and crimes against humanity. Procedurally, ICL offences can be heard in international, hybrid and domestic jurisdictions, but it is important to note that the reach of ICL is imperfect and often relies on states to codify specific crimes. Many ICL offences grow out of public international 
law concerns over state responsibility regarding a state's citizens, international human rights law (IHRL), as well as a state's conduct of hostilities, international humanitarian law (IHL). Under these regimes, states may be held responsible for breaches of both customary and treaty norms. States will also often be required to criminalise and prosecute or extradite individuals suspected of breaching these various norms. Thus, ICL takes norms initially applicable to states and transforms them into individual criminal offences. The irony in this system-particularly for IHRL-is that, although it depicts the state as predatory and in need of restraint (Cogan 2011: 331-7, 342-3), its normative impetus is state action/consent, whether through treaty or customary law. Thus, rights and responsibilities as well as individual and state liabilities intersect at domestic, international, transnational and global levels in increasingly complex and sometimes antagonistic ways.

The greater emphasis on individual rights within IHRL (see Charlesworth, Chapter 21, this volume) is also now reflected in an increasing focus on individual responsibility for crimes committed during peace and particularly during conflict in international criminal law. We can therefore understand IHRL and ICL as opposing and complementary trends within the international legal field's focus on the individual as situated within a global (rather than a national) community.

[Yet the] paradox at the heart of this twin project (international criminal law and international human rights law) is that while its core animating idea is the abolition of all distinctions within humanity, some of its most energetic practices are dedicated to punishing 'inhumane' acts ... and acting on behalf of humanity against those who are deemed to have stepped outside or defied humanity. (Simpson 2012: 115-16)

A shift towards individual criminal responsibility is a manifestation of neoliberal governance, which tends to obscure structural dimensions of conflict and only works towards 'negative peace' (or the absence of violence) (Nouwen 2012: 332). In addition, Kendall (2011: 587) identifies the 'neo-liberal premise that justice can be subjected to market rationalities', including the increasing prominence of private, donor-led initiatives. It is not surprising, then, that despite ICL's post-World War I genesis, it has come to flourish in the post-Cold War international system. 
Focusing on individual perpetrators simplifies the complexities of responsibility in modern life (Drumbl 2007: 35). Within the realms of an international criminal trial, highly complex conflicts can be 'lifted outside of worldly politics and into a morally unambiguous realm of good and evil' (Orford 2011: 186).

[Focusing] on the idea of international criminal justice helps us to forget that an overwhelming majority of ... crucial problems ... are not adequately addressed by criminal law ... The seemingly unambiguous notions of innocence and guilt create patterns of causality in the chaos of intertwined problems of social, political and economic deprivation surrounding the violence. (Tallgren 2002: 593-4)

Critiques of ICL focus particularly on the way it obscures profoundly political situations through techniques of criminalisation, legalisation and juridification (Simpson 2008; S Dezalay 2012). A study of ICL as governance, then, must be attuned to the politics shaping and being produced within the matrix of a range of ICL practices. Although intimately reliant on states and societies for its impetus and normativity, ICL as a governance tool overexposes the role and responsibility of an alleged individual criminal for the most heinous and often the most systemic of acts, such as genocide, apartheid and crimes against humanity (Cryer 2005: 985).

This chapter first examines the evolution of ICL as a field of practice and scholarship. It then considers the central actors and institutions within ICL before considering its normative substance and boundaries. The chapter ends by evaluating the contribution that ICL makes to the governance of intersecting domestic, international, transnational and global spaces.

\section{Mapping the rise of the ICL field and associated projects}

The rise of ICL can be recounted in many ways, but, for the purposes of this chapter, it is important to understand how ICL emerged as a key component of managing conflict-torn and post-conflict societies across the developing world since the end of the Cold War. In this way, we can see ICL as an example of regulatory globalisation that has favoured the interests of the global North, such as in the case of global business regulation (Braithwaite and Drahos 2000). We must also appreciate the 
ways in which ICL was built on, and has even colonised, other fields, particularly human rights and transitional justice. Finally, although it is beyond the scope of this chapter, we need to be aware of how progressivist histories of ICL justify its place today as a key global governance tool.

Compared with its domestic counterpart of criminal law, ICL springs from immature roots. It is for this reason that Dubber (2011: 930) describes ICL as 'ahistorical' and 'a pioneer project to boldly go where no one has gone before'. When origins are needed, however, dominant historical accounts within ICL tend to overlook efforts during the interwar years and begin with the Nuremberg and Tokyo international military tribunals (IMTs) after World War II. The Cold War figures as a pause in a narrative of progress that then resumes with the ever-growing importance of ICL through the proliferation of international criminal tribunals (ICTs) from the 1990s onwards, which I consider in Section 3 (Skouteris 2010: Chapter 4).

Although the IMTs remain a watershed moment for ICL, what has been more significant is the rise of human rights as a discourse and set of mechanisms during democratic transitions from the 1970s onwards. Like ICL, the practical promise of IHRL remained largely unfulfilled for the first few decades after the Universal Declaration on Human Rights of 1948 as Cold War politics shifted attention to other projects. According to Dezalay and Garth (2006: 239), Chile served as a laboratory for human rights, where activists learned to frame their claims less in domestic, constitutional law idioms, and more in universal, IHRL-centred language (see also Moyn 2010). Human rights framing and various transitional justice techniques became dominant tools for societies in transition throughout the 1970s and 1980s, especially in Latin America and Eastern Europe. Invoking international or universal norms became even more acceptable once the Cold War ended and the best way to do this was through recourse to human rights in increasingly technical and legal registers. Humanitarian actors discovered that professionalised legal discourse attracted donor funding and this, in turn, contributed to the juridification of public discourse (S Dezalay 2012: 72-3) alongside massive institutional investments in international trials (Levi and Hagan 2012: 15).

Thus, the meteoric rise of the ICL industry (Tallgren 2015: 137) is very much a product of the post-Cold War world that allowed for greater multilateralism within the context of numerous ongoing and emergent civil conflicts and the triumph of neoliberalism. No longer paralysed by 
superpower rivalry, the United Nations (UN), in particular, could devote greater attention and resources to peacekeeping operations. According to Orford:

[the] expansive apparatus of techniques developed at the UN for conflict-prevention, peacekeeping and civil administration would no longer be limited to filling a political, economic, social or military vacuum. Instead, they would be used for detecting possible causes of conflict and acting early to prevent disputes arising. (Orford 2011: 91)

The de jure obstacles of non-intervention and state sovereignty (as per Article 2(4) of the UN Charter) were eroded by an emphasis on de facto questions about state capacity and willingness to protect populations, particularly within the idiom of human rights (Mazower 2012: 379-80,388). Legal requirements of state consent or UN Security Council (UNSC) Chapter 7 authorisation became less important in the face of overwhelming humanitarian concerns that gave rise to the emergence of the 'Responsibility to Protect' doctrine. This new humanitarianism (of militarised care) or 'humanity law' (Teitel 2011) was not simply a product of state-level multilateralism, however, as such activities were supported and extended by proliferating civil society actors, particularly within the interrelated aid, development and human rights sectors. Thus, in instances where certain states were deemed by the 'international community' to be incapable of protecting their populations, both public and private actors operating within this global arena were ready to intervene and directly assist such populations with far more than emergency relief. According to Sara Dezalay (2012), we can understand the post-Cold War era as producing a conflation of development and security that, in turn, has enabled the transformation of (underdeveloped) societies through various forms of intervention, whether military or legal.

It was within such a context of UN operations, human rights consciousness and debates about humanitarian intervention that ICL emerged as a central tool for shaping conflict-affected and post-conflict states (Mazower 2012: 396). Despite much of ICL's institutional and normative architecture being the product of classic state-based-consent international law, it is also very much a product of UN design. This is illustrated by the UNSC's responses to two of the most significant conflict-based humanitarian crises of the 1990s: the dissolution of the Yugoslav Republic and the Rwandan genocide. In both cases, the UNSC acted under Chapter VII to create ad hoc ICTs tasked with 'prosecuting 
persons responsible for serious violations of international humanitarian law' (UNSC Resolution 827 (1993)). This marked a radical departure vis-a-vis interpretations of the council's powers to determine and act on threats to international peace and security (UN Charter, Article 39). ${ }^{1}$ This concern with international criminal justice significantly expanded the remit of the UNSC beyond a model of simple conflict prevention and, occasionally, collective security. Such UNSC institution building precipitated the establishment of a number of other ICTs, including ICL's permanent forum, the International Criminal Court (ICC), explored below.

What is important to note here in our discussion about the expanding powers of the UNSC as refracted through ICL is the way in which a series of crises has led to the institutionalisation of international criminal interventions backed by the police powers of the UNSC. Although the UN General Assembly had originally been the main UN body to support the ICC's creation (Mazower 2012: 399), the UNSC's key role in determining threats to the peace or acts of aggression under Chapter VII of the UN Charter as well as its power under the Rome Statute to refer cases to the ICC have placed this highly political body at the centre of ICL practice. Through this interplay between law and politics, along with crisis and institutionalised norm, we see how the UNSC's turn to ICL is emblematic of international law as a discipline of and a discipline in crisis (Charlesworth 2002). As a practice, ICL straddles crisis and norm through its focus on exceptional events that are then juridified and institutionalised most powerfully in ICT prosecutions.

\section{Delimiting the field: ICL actors, institutions and effects}

Although ICL is increasingly seen as a default governance tool, we need to understand how the 'apparent normative consensus' on the increasing resort to ICL 'comes to be presented as such'(Levi and Hagan 2012: 14). This is particularly apparent during armed conflict where calls for 'global justice' are often linked with support for international criminal trials (Nouwen and Werner 2015: 163). In this section, I touch on how ICL

1 See also Prosecutor $v$ Dusko Tadic (Judgment) (International Criminal Tribunal for the former Yugoslavia, Appeals Chamber, Case No. IT-94-1-A, 15 July 1999). 
has become naturalised through the pioneering role of 'lawyer-brokers', how they operate within the transnational conflict or criminal justice field and how ICTs were established within this milieu.

As a result of the processes outlined above in the post-Cold War world, including the juridification of public discourse, lawyers have become central figures in the interrelated fields of human rights and ICL. Within a climate of 'humanitarianism' and greater consciousness of others' suffering, international lawyers felt the urge to 'do something' with the law (Orford 1998: 11). The elaboration of rights was not enough and, instead, it is ICL, with its enforcement 'teeth', that has allowed international lawyers to be part of a 'global responsibility to protect' (Nouwen 2012: 329). Critical international law scholarship on ICL has noted how international criminal lawyers operate through a deeply set (and, often, un-self-reflexive) faith in ICL's promise of ending impunity (Koller 2008). This could be the product of who populates the ICL field as:

the boundaries between academia, advocacy, and practice are perhaps at their most narrow in the field; international criminal justice is symbolically and uncritically equated in mainstream academia with the triumph of the human rights movement. (Byrne 2013:1000)

A number of socio-legal accounts have highlighted how legalisation of conflict has provided new opportunities for international lawyers. Where once lawyers tended to act in response to conflict, they began to act pre-emptively by defining 'the scope of the problem itself' (Levi and Hagan 2012: 38). Lawyers now increasingly act as brokers who can frame a range of crises in highly expert idioms that then preclude the authority of other non-legal experts. Such reframing of problems also assures jobs and prestige as "[1]awyer-brokers play a key role in building and legitimating the market in their services and expertise'(Dezalay and Garth 2012: 279). One of the best ways of consolidating authority is through institution building (Kauppi and Madsen 2014: 328), which is exemplified by the proliferation of the ICL field, which can boast an upward trajectory of ICTs, ICL journals and ICL university courses.

For Hagan and Levi, the end of the Cold War presented new opportunities for lawyers, particularly in North America, to internationalise the governance of war crimes. Thus, lawyers were seminal in the emergence of what Sara Dezalay calls the conflict field. Within the conflict or international criminal justice field, lawyers and legalisation were what 
came to dominate governance practices. In particular, 'justice' came to be understood in increasingly narrow and legalistic ways. Thus, for Kamari Clarke (2009: 13), much of ICL's success is a product of select actors and institutions being able to obscure and silence other justice narratives.

If we understandICLas an unmediated relationship between international law and the individual — whether as victim or accused — then, for Cogan, this is illustrative of the regulatory turn within international law more broadly, which straddles the contradictory traditions of human rights and law enforcement. This contest is epitomised by ICL itself:

With the reduction in the fear of governmental power, the limits on the ability to enforce human rights through state action dissipated significantly. The move to create international criminal tribunals (especially the International Criminal Court); the specification of international crimes (such as war crimes and crimes against humanity); the increasing demands of human rights treaty bodies for states to take positive action, including coercive action, to apply and enforce the law against individuals in their private capacity; the elaboration and criminalization of violations of human rights norms ... and the attempted innovations in the concept of universal jurisdiction represent, to many, a natural extension of the human rights movement. (Cogan 2011: 359-60)

The crucial word in this quotation is 'natural', capturing how ICL has built on and, in many instances, colonised other transnational fields, including the human rights field.

Perhaps the best way of understanding ICL's reach is through an examination of ICTs and their disproportionate focus on the global South. The blueprints for all later ICTs were the two UNSC-created ad hoc tribunals mentioned above, the International Criminal Tribunal for Rwanda and the International Criminal Tribunal for the former Yugoslavia in the mid-1990s. Based on Chapter VII of the UN Charter, their jurisdiction prevailed over all other domestic and international legal forums. Yet, unable to deal with the vast number of potential perpetrators, both tribunals required domestic counterparts to fill at least some of the gaps in their purview. These two examples were used as laboratories for the newly emerging ICL field and it was crucial that they served as exemplars of international standards. Such aspirations, as well as the nature of the hearings themselves, have produced incredibly lengthy and costly trials whose outcomes could never be satisfying to everyone. 
A range of civil society, state and IGO actors, building on the example of these two ICTs and the lessons learnt, was galvanised to work towards the establishment of a permanent international criminal tribunal, the ICC (Tallgren 1999: 359-60). The UN General Assembly requested the International Law Commission (ILC) to work on a draft statute for the court and, during the mid-1990s, a series of meetings was convened in New York that brought together state and civil society actors. This activity culminated in the Rome Conference of 1998, which was sealed with the signing of the ICC Statute, which came into force in 2002 with 60 ratifications (there are now 122 parties). This statute and the court itself were and remain the highpoint of ICL governance, but it is important to note the ICC's many limitations in the face of such hope and the nature of its work to date. In particular, the court is restricted in its capacity due to finite resources and an imperfect jurisdictional reach. The court's jurisdiction is founded, first, via referral to the prosecutor by a state party (Article 14); second, through a referral by the UNSC (Article 13); and third, on the initiative of the prosecutor her/himself (Article 15). Although it may seem strange for states to initiate cases themselvesespecially over contentious civil conflicts, as in the examples of Mali, the Democratic Republic of Congo, the Central African Republic and Uganda, so-called 'self-referrals' in fact indicate how the ICC tends to rely on state-centric accounts for some of its work (Nouwen 2012: 336; Robinson 2011). For example, Uganda's self-referral in relation to the situation in the north of the country with the Lord's Resistance Army was a way of legitimising its own narrative about the conflict (Nouwen and Werner 2010: 948). In contrast with Uganda, the conflict in Darfur came under the court's remit through UNSC referral. Although Sudan's president has been indicted, he remains able to travel widely across the African continent, indicating the deep distrust about at least part of the ICC's current focus, where its docket is populated almost exclusively by African situations (the exception being Georgia, along with a number of non-African jurisdictions under preliminary examination). Clarke (2009: 46-9) goes as far as to describe the court's work as the tribunalisation of African violence, amounting to a new scramble for Africa. These examples illustrate how ICL is increasingly being used as a way of framing conflict and the development of post-conflict societies across the global South.

ICL's reach is not based solely on ICTs, however, as it also extends directly into the domestic realm in a number of ways, including through a range of more localised tribunals. Closely linked to the 
institutional legacies of the ICT on Rwanda, the ICT on the former Yugoslavia and the ICC are mixed, hybrid or internationalised tribunals that tend to oversee transitions by bringing together domestic and international norms and practice within the affected state. Examples include Cambodia, Timor-Leste, Bosnia, Sierra Leone and Kosovo. Where the 'international community' has deemed the domestic setting to be unaccommodating to a trial process, it is also possible to move domestic criminal proceedings outside the crime site, such as the ICT for the former Yugoslavia and the Special Tribunal for Lebanon (BurgisKasthala 2013) in The Hague and the ICT for Rwanda in Arusha, Tanzania.

\section{ICL normativities: Protecting humanity through individual criminal responsibility within and beyond the state}

This overview of international and mixed international criminal tribunals above highlights how states, IGOs, NGOs as well as lawyer-brokers have all been crucial in contributing to ICL as an exemplar of the regulatory turn within international law more broadly. As introduced above, Cogan's (2011) notion of this regulatory turn is distinguished from a dominant Cold War approach of mediated law as between international governance and the individual to a growing post-Cold War emphasis on unmediated or direct regulation of the individual. ICL came early to this trend through the 1948 Genocide Convention and the 1973 International Convention on the Suppression and Punishment of the Crime of Apartheid. By the turn of the century, the regulatory turn in:

international law manifested itself in three ways: the establishment of direct international duties and their direct enforcement; the expansion of mediated law's coverage and the increasing specificity in which that law was outlined; and the extension and the particularising of facilitative law and processes. (Cogan 2011: 346)

Although it would appear that ICL is particularly reliant on the first element of direct international duties and their international enforcement through the proliferation of ICTs, in fact, its greatest reach arises from both unmediated and mediated laws at the domestic level. For, although ICTs are a crucial element of ICL's development, 
their limited capacities mean that domestic criminal prosecutions of international crimes are as or more important for consolidating the reach of ICL. States have enacted legislation as required by treaty, but some have also acted pre-emptively to preclude possible international adjudication. Most generally, states can invoke ICL norms through the resort to universal jurisdiction for a range of international crimes irrespective of their location, the perpetrator or the victim. A well-known example of this is the Pinochet case, ${ }^{2}$ which relied on a universalist interpretation of torture as crime. In 2000, the UK House of Lords determined that a former head of state was extraditable for alleged crimes of torture committed during his rule and, even though he never faced trial in Spain due to ill health, this did not detract from the principle of universal jurisdiction. Such recognition of ICL's domestic dimension is also embodied in the notion of complementarity within the ICC, where domestic jurisdiction is the rebuttable presumption for alleged crimes (Articles 17-20). As ICL's central concern is impunity, it is not significant whether a fair trial occurs domestically or internationally. Under the policy of ICC complementarity, states are required to demonstrate how their criminal justice systems are adequate in responding to allegations before the court, highlighting how ICL can have far-reaching effects on domestic jurisdictions. The ICC can underscore such practices through entering into partnership agreements with host states, such as in the case of Libya. Other states, IGOs and NGOs can also play a facilitative role in this policy of 'positive complementarity', whose 'explicit aim is to catalyse developments at the domestic level' either directly or indirectly (Nouwen 2013: 104).

Whether an ICL trial occurs domestically, internationally or in some hybrid forum, the common result is the framing of individual criminal responsibility for acts that often straddle the fields of IHL, IHRL and ICL. Recalling the most elementary dimension of crime, we need to ask here what is the harm being regulated, who is deemed to be the perpetrator, who is the victim and which social world informs underlying narratives of harm and criminality? Although ICL often does play out domestically, it is crucial to recognise not simply its international dimension (as the product of crimes created by states), but also its global quality as a practice that constructs 'humanity' as its source, telos and site of regulation (Corrias and Gordon 2015). Regardless of whether humanity as a constituency or political community exists, the idea of

$2 \quad R v$ Bow Street Magistrates Ex P Pinochet [2001] 1 A.C. 147. House of Lords. 
humanity serves as the central trope in the dominant ICL narrative of progress through law. In this narrative, states are the ones who facilitate ICL's reach, but states are rarely the ones responsible for its breaches, particularly states from the global North. Recalcitrant states may be brought within the fold through capacity building and criminalisation, while, ultimately, individuals are the ones who are held out and sanctioned as enemies of humanity for the most serious of acts (Dubber 2011: 932), including genocide, crimes against humanity and war crimes. The most 'political' of crimes-aggression-implicates the state more than any other crime and perhaps, then, it is why this offence has been so difficult to institutionalise within current ICL structures. Once the ICC potentially considers allegations of aggression after 2017, however, the difficulties of criminalising political projects will only highlight more starkly the particular biases inherent in a resort to individual criminal responsibility for (certain, probably non-Western-instigated) wars of aggression.

\section{Conclusion}

International criminal law is an increasingly prominent example of the globalisation of regulation (see Drahos, Chapter 15, this volume) vis-avis conflict-torn and post-conflict states, whose reach extends far beyond the prosecution of rogue individuals; its broader remit is to reconfigure 'incapable' states and societies in the global South. This globalisation of criminal law can be contrasted with a globalisation that aimed at repairing relations through principles of restorative justice and responsiveness (see Braithwaite, Chapter 7, this volume). Despite its name:

[the] project of international criminal law is global, rather than international, insofar as it concerns itself not with the interaction of nations or with nations taken individually, but with individuals' relationship to humanity globally speaking; the offender of international criminal law offends humanity anywhere and everywhere, regardless of national affiliation. (Dubber 2011: 934, emphasis in original)

The ICL project is also a political one that seeks to confine questions of social redress and repair within extremely limited registers. Where once justice could capture a variety of practices, when invoked through the international criminal justice field, it has become synonymous with 
trials of individual criminal responsibility. ICL governance, then, relies on techniques of depoliticisation and juridification to advance liberal and neoliberal rationalities for often divided and peripheral societies.

\section{Further reading}

Cryer, R, Friman, H, Robinson, D and Wilmshurst, E 2014. An Introduction to International Criminal Law and Procedure. 3rd edn. Cambridge: Cambridge University Press.

Ratner, SR, Abrams, JS and Bischoff, JL 2009. Accountability for Human Rights Atrocities in International Law: Beyond the Nuremberg Legacy. 3rd edn. Oxford: Oxford University Press.

\section{References}

Braithwaite,J and Drahos, P 2000. Global Business Regulation. Cambridge: Cambridge University Press.

Burgis-Kasthala, M 2013. 'Defining justice through transition? International and domestic contestations over the Special Tribunal for Lebanon', International Journal of Transitional Justice 7(3): 497-517. doi.org/10.1093/ijtj/ijt014.

Byrne, R 2013. 'Drawing the missing map: What socio-legal research can offer to international criminal trial practice', Leiden Journal of International Law 26(4): 991-1007. doi.org/10.1017/ S0922156513000514.

Charlesworth, H 2002. 'International law: A discipline in crisis', Modern Law Review 65(3): 377-92. doi.org/10.1111/1468-2230.00385.

Clarke, KM 2009. Fictions of Justice: The International Criminal Court and the Challenge of Legal Pluralism in Sub-Saharan Africa. Cambridge: Cambridge University Press. doi.org/10.1017/CBO9780511626869.

Cogan, JK 2011. 'The regulatory turn in international law', Harvard International Law Journal 52(2): 322-72. 
Corrias, L and Gordon, G 2015. 'Judging in the name of humanity: International criminal tribunals and the representation of a global public', Journal of International Criminal Justice 13(1): 97-112. doi. org/10.1093/jicj/mqu083.

Cryer, R 2005. 'International criminal law vs state sovereignty: Another round?', European Journal of International Law 16(5): 979-1000. doi.org/10.1093/ejil/chi156.

Dezalay, S 2012. 'Lawyering war or talking peace? On militant usages of the law in the resolution of internal armed conflicts: A case study of international alert', in Y Dezalay and BG Garth (eds), Lawyers and the Construction of Transnational Justice. Abingdon, UK: Routledge, pp. 60-83.

Dezalay, Y and Garth, BG 2006. 'From the Cold War to Kosovo: The rise and renewal of international human rights', Annual Review of Law and Social Science 2: 231-55. doi.org/10.1146/annurev. lawsocsci.2.032406.145708.

Dezalay, Y and Garth, BG 2012. 'Marketing and legitimating two sides of transnational justice: Possible trajectories toward a unified transnational field', in Y Dezalay and BG Garth (eds), Lawyers and the Construction of Transnational Justice. Abingdon, UK: Routledge, pp. 277-95.

Drumbl, MA 2007. Atrocity, Punishment, and International Law. Cambridge: Cambridge University Press. doi.org/10.1017/ CBO9780511611100.

Dubber, MD 2011. 'Common civility: The culture of alegality in international criminal law', Leiden Journal of International Law 24(4): 923-36. doi.org/10.1017/S0922156511000434.

Harman, S and Williams, D 2013. 'Introduction: governing the world?', in S Harman and D Williams (eds), Governing the World? Cases in Global Governance. Abingdon, UK: Routledge, pp. 1-10. doi. org/10.3726/978-1-4539-1145-7/5.

Kauppi, N and Madsen, MR 2014. 'Fields of global governance: How transnational power elites can make global governance intelligible', International Political Sociology 8(3): 324-30. doi.org/10.1111/ ips.12060. 
Kendall, S 2011. 'Donors' justice: Recasting international criminal accountability', Leiden Journal of International Law 24(3): 585-606. doi.org/10.1017/S0922156511000264.

Koller, D 2008. 'The faith of the international criminal lawyer', New York University Journal of International Law and Politics 40: 1019-69.

Koskenniemi, M 2007. 'The fate of public international law: Between technique and politics', Modern Law Review 70(1): 1-30. doi. org/10.1111/j.1468-2230.2006.00624.x.

Levi, R and Hagan, J 2012. 'Lawyers, humanitarian emergencies and the politics of large numbers', in Y Dezalay and BG Garth (eds), Lawyers and the Construction of Transnational Justice. Abingdon, UK: Routledge, pp. 13-47.

Mazower, M 2012. Governing the World: The History of an Idea. London: Allen Lane.

Moyn, S 2010. The Last Utopia: Human Rights in History. Cambridge, Mass.: Harvard University Press.

Nouwen, SMH 2012. 'Justifying justice', in J Crawford and M Koskenniemi (eds), The Cambridge Companion to International Law. Cambridge: Cambridge University Press, pp. 327-51. doi. org/10.1017/CCO9781139035651.021.

Nouwen, SMH 2013. Complementarity in the Line of Fire: The Catalysing Effect of the International Criminal Court in Uganda and Sudan. Cambridge: Cambridge University Press. doi.org/10.1017/ CBO9780511863264.

Nouwen, SMH and Werner, WG 2010. 'Doing justice to the political: The International Criminal Court in Uganda and Sudan', European Journal of International Law 21(4): 941-65. doi.org/10.1093/ejil/ chq064.

Nouwen, SMH and Werner, WG 2015. 'Monopolizing global justice: International criminal law as challenge to human diversity', Journal of International Criminal Justice 13(1): 157-76. doi. org/10.1093/jicj/mqu078. 
Orford, A 1998. 'Embodying internationalism: The making of international lawyers', Australian Year Book of International Law 19: $1-34$.

Orford, A 2011. International Authority and the Responsibility to Protect. Cambridge: Cambridge University Press. doi.org/10.1017/ CBO9780511973574.

Robinson, D 2011. 'The controversy over territorial state referrals and reflections on ICL discourse', Journal of International Criminal Justice 9(2): 355-84. doi.org/10.1093/jicj/mqr009.

Simpson, G 2008. “'Stop calling it aggression”: War as crime', Current Legal Problems 61(1): 191-228. doi.org/10.1093/clp/61.1.191.

Simpson, G 2012. 'Atrocity, law, humanity: Punishing human rights violators', in C Gearty and C Douzinas (eds), The Cambridge Companion to Human Rights Law. Cambridge: Cambridge University Press, pp. 114-33. doi.org/10.1017/CCO9781139060875.010.

Skouteris, T 2010. The Notion of Progress in International Law Discourse. The Hague: Asser Press.

Tallgren, I 1999. 'We did it? The vertigo of law and everyday life at the diplomatic conference on the establishment of an international criminal court', Leiden Journal of International Law 12(3): 683-707. doi.org/10.1017/S0922156599000369.

Tallgren, I 2002. 'The sensibility and sense of international criminal justice', European Journal of International Law 13(3): 561-95. doi. org/10.1093/ejil/13.3.561.

Tallgren,I 2015.'The voice of the international:Who is speaking?', Journal of International Criminal Justice 13(1): 135-55. doi.org/10.1093/jicj/ mqu086.

Teitel, RG 2011. Humanity's Law. Oxford: Oxford University Press. doi. org/10.1093/acprof:oso/9780195370911.001.0001. 
This text is taken from Regulatory Theory: Foundations and applications, edited by Peter Drahos, published 2017 by ANU Press, The Australian National University, Canberra, Australia. 